\title{
ECOPISTOR
}

UUW.ECONSTOR.EU

Der Open-Access-Publikationsserver der ZBW - Leibniz-Informationszentrum Wirtschaft The Open Access Publication Server of the ZBW - Leibniz Information Centre for Economics

Josheski, Dushko

\section{Preprint \\ Personnel Economics essay: Issues in Human Capital Theory, training and earnings of workers}

Suggested Citation: Josheski, Dushko (2014) : Personnel Economics essay: Issues in Human Capital Theory, training and earnings of workers

This Version is available at: http://hdl.handle.net/10419/90913

Nutzungsbedingungen:

Die ZBW räumt Ihnen als Nutzerin/Nutzer das unentgeltliche,

räumlich unbeschränkte und zeitlich auf die Dauer des Schutzrechts beschränkte einfache Recht ein, das ausgewählte Werk im Rahmen der unter

$\rightarrow$ http://www.econstor.eu/dspace/Nutzungsbedingungen nachzulesenden vollständigen Nutzungsbedingungen zu vervielfältigen, mit denen die Nutzerin/der Nutzer sich durch die erste Nutzung einverstanden erklärt.
Terms of use:

The ZBW grants you, the user, the non-exclusive right to use the selected work free of charge, territorially unrestricted and within the time limit of the term of the property rights according to the terms specified at

$\rightarrow$ http://www.econstor.eu/dspace/Nutzungsbedingungen

$B y$ the first use of the selected work the user agrees and declares to comply with these terms of use. 


\title{
Personnel Economics essay: Issues in Human Capital Theory, training and earnings of workers
}

\author{
Dushko Josheski ${ }^{1}$ \\ Researcher in the field of applied economics mainly also covers topics from wide area of macroeconomics and \\ international trade and econometrics, \\ University Goce Delcev-Stip, R.Macedonia
}

\begin{abstract}
In this paper the issues from the personnel economics has been investigated. The issues such as training of workers from Becker's human capital theory and their association with the workers' productivity. In the second part of the paper the issue of grooming has been investigated in relation with earnings for which there exist and it is presented empirical evidence. In the equation as regressors are also present Mincerian variables: age, marital status and others. Also the four puzzles in the empirical literature about the determinants of earnings has been investigated. And how the empirical literature helps in resolving them.
\end{abstract}

Keywords: Personnel economics, training, earnings, grooming

1. Investigation of the two puzzles which Becker's human capital theory of training does not explain. Examination whether the presence of oligopsony and asymmetric information resolves them?

Becker's human capital theory recognizes two types of training- general and specific. General training is transferable across companies as individuals change jobs, worker gets all the returns and he is the one that finances the training. Table $1.1^{2}$ row 1clarifies that according to human capital theory in perfect competition, there is no difference between wages and the productivity during the training in period of lower productivity workers are compensated by lower wages and afterwards they are compensated by higher wages. Post-training wages are same across the subsequent firms as they are in the current firm. Specific training increases productivity only in the current firm. In row 3 from table 1 firm and the worker share the cost and the returns of the training investment to avoid hold-up problems. Wages are above the productivity during the training and below marginal productivity after the training. Because it is not transferable across the firms wages at

\footnotetext{
${ }^{1}$ Authors email: dushkojosheski@gmail.com

2 See Appendix 1
} 
subsequent firms are lower than marginal productivity. In row 2 from table 1 human capital theory recognizes divergence between wages and net marginal productivity when firms decide to participate in financing of general training when workers face credit constraints i.e. they are not able to borrow. Firm pays workers more than marginal productivity during the training and less afterwards. Firm acts as lender, but in a situation only if there is apprenticeship contract, to bind the workers after the training until the loan has been paid back. And second puzzle that cannot be explained within the human capital theory framework is that workers do not receive wage cuts during the training. Theory of oligopsony provides insights that can explain these two puzzles. According to the classical theory of oligopsony firms have market power in setting the wages because they are the only employer. By the new theory oligopsony arises through product differentiation and imperfect information. Product differentiation requires from workers, working in such companies to possess specific skills which increases the costs of mobility of workers and workers , and workers do not have incentives to invest in general training. Asymmetric information exists in case when firm knows the value of its general training but other firms do not. If outsiders assign zero value to the training -such training is in effect specific for the training firm. As, post productivity returns to training are higher than wage returns, firms find profitable to pay for the general training as can be seen in fig1 and in column 5 from table 1.1.

Figure 1 Post productivity returns to training are higher than wage returns

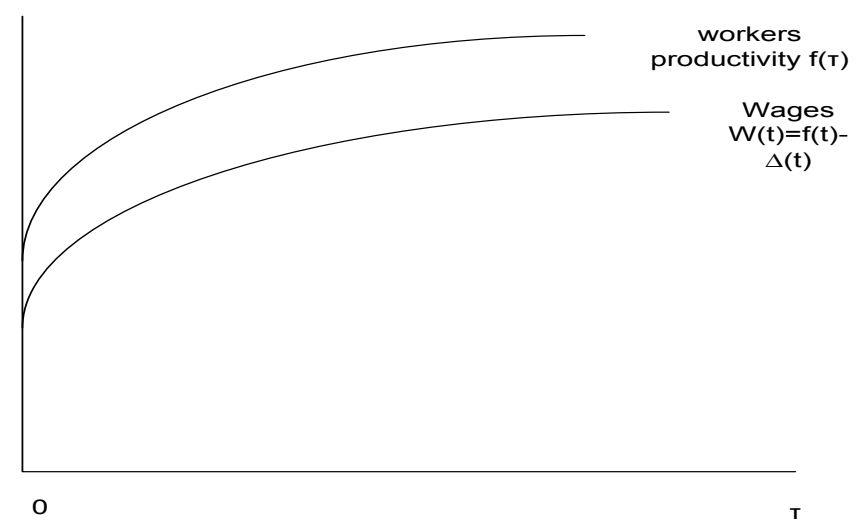

In Oligopsonistic labour market wages are lower than marginal productivity.

\section{Can economics analysis provide additional insights into why workers "invest" in} grooming? What are the main limitations of this analysis?

Economics literature has focused almost exclusively on the effect of innate (exogenous) beauty on market outcomes; other disciplines have considered effect on grooming as (endogenous) aspect of physical appearance to be important to all the manners of social and economic life. Businesses 
recognize the importance of what the literature refers to as "personal branding". Grooming can provide powerful market signals. Workers who spend more effort grooming will enjoy more favourable market outcomes. The wage regression of an individual $i$ of gender type $j$ is given by: $\ln W_{j i}=X_{1 j i} \Gamma_{1 \mathrm{j}}+\mathrm{X}_{2 \mathrm{ji}} \Gamma_{2 \mathrm{j}}+\beta_{\mathrm{j}} \ln \mathrm{G}_{\mathrm{ji}}+\mathrm{U}_{\mathrm{ji}}, \mathrm{j}=$ male, female here $\ln \mathrm{W}$ is the log of weekly wages for males and females working full time, ( 35 hours or more per week) $X_{i}$ is the matrix of Mincerian human capital determinants like age, marital status, $\mathrm{X}_{2}$ represents the matrix of controls for location, industry occupation. $G$ represents the time spent on personal grooming. In general represents the time spent by workers on washing, dressing. $\beta$, represents the marginal returns in weekly wages to time spent grooming. By introducing grooming in its log form the model allows for diminishing returns. It is expected $\beta>0$ and the time allocated to grooming is endogenous, grooming habits are determined in the culture. And $\beta$ will be biased upward if higher wages lead to more grooming, and biased towards zero if increase wages cause less grooming. Second equation is therefore grooming equation $\ln G_{j i}=I_{j i} \Gamma_{3 j}+\alpha_{j} \ln W_{j i}+E_{j i}, j=$ male, female $I$ represents matrix of exogenous variables that determine the time spent on grooming (personal traits), and wages in log. Two types of factors are considered (1) household characteristics (2) other activities with ones social life. In tables $4 \& 5^{3}$ results are obtained by 2SLS and generalized method of moments and (GMM).In table 4, 3068 observations version of first (i) using log of grooming as an explanatory variable (ii) adding a dummy interaction to account for possible racial disparities regarding the returns to grooming, in table 5 there are 2837 observations, and in the two tables standard theoretical predictions are confirmed. The returns to age, which proxy labour experience are positive statistically significant in the early years, but negative in later years negative sign on $\mathrm{AGE}^{2} / 100$. Whites earn more than their minority counterparts, education contributes positively to earnings. Marriage has positive effect on men's wages but has no significant effect on those of women. Extra time spent on grooming has positive significant effect for men that earn $5 \%$ higher wages; this coefficient is positive but insignificant for women's earnings. There is also week evidence than the returns to grooming by race for males and females. One problem with this analysis is the weak instruments and the second is the validity of instruments, IVs must not be correlated with wages. To test validity of the IVs it is used Hansen J (distributed $\chi^{2}$ ) and heteroscedasticity problem which should be corrected in the first stage by OLS to use the 2SLS if not GMM should be used. Also, coefficient on grooming may be biased because grooming and beauty may be correlated.

\footnotetext{
${ }^{3}$ See Appendix 2
} 
3. What are the four puzzles which Bowles et al. (2001) identify in the empirical literature on the determinants of earnings? In what sense are they "puzzles"?

First, apparently similar individuals receive quite different earnings. The puzzle is to understand how in the standard earning equation for the individuals of the same race, sex, between $2 / 3$ and $4 / 5$ of the variance of natural logarithm of hourly wages of individuals is explained by a person's age ,year of schooling, occupation, and income. Second puzzle is to understand, what is that successful parent's pass on to their children that gives them labour market advantages beyond the superior schooling, or cognitive scores measured in available studies. Third puzzle is to explain why apparently irrelevant personal traits (beauty, height, and obesity) are often robust predictors of earnings. Fourth puzzle is to explain why the apparent impact of school resources on earnings might be so different from their apparent effects on subsequent earnings. On survey of 3,000 employers the most important was the "attitude" and "communication skills" compared with the "years of schooling" and "academic performance". The second example in a Survey 1,693 British employers identify "poor attitude, motivation or personality" as recruitment problem in $62 \%$ of the cases, while "lack of technical skills" in $43 \%$.The third empirical example is from a series of studies on the labour market impact of the GED, a diploma gained by a test of cognitive skills taken by a large fraction of dropouts from US high schools. Heckman and his co-authors reason that GED is mixed signal indicating to the employers that the individual had cognitive skill to complete high school but lacked the motivational or behavioural requisites. These examples illustrate a possible bias, "skill shortages" when there is difficulty in recruiting suitable employees. And second bias is the presumption that anything rewarded in a competitive labour market must be a skill. Model in which trait that is not skill may be rewarded in a competitive labour market. If disequilibrium rents arising from technological shocks are persistent and if labour services are not subject to costless enforceable contracts, individual behavioural traits unrelated to productive capacities may bear a positive price.

\section{Interpretation of the meaning of Bowles et al.'s term “incentive enhancing} preferences". And to what extent, the behavioural model can resolve the puzzles identified in Question 3.

Coasean traits are defined as "incentive enhancing preferences" including such personality traits as a sense of efficacy avoiding disruptive behaviour, as determinants of earnings. They do not contribute directly to the production and they are in the Coasean model of earnings, determination 
which has been explored by sociologists that frequently stress the non-skilled related determinants of earnings and of the contribution of schooling to the economy. Increase in" incentive enhancing preferences "will lead an employee to work harder. Examples of "incentive enhancing preferences "are: individual's evaluations, of the prospect of retaining the job in the future, efficacy as opposite of fatalism (incentive depressing trait), and third example is desirability of holding the job. In table $2^{4}$ are presented results from: (NLSYW) National Longitudinal Survey of Young Women and National Child Development Study (NCDS) both data sets are presented in two columns one for the extended human capital model; and another one for behavioural model .In column A the estimated signs of the variables (years of education, IQ score, Years of work experience, Parental SES) are positive consistent with the literature, number of children variable is with negative sign. In column $\mathrm{B}$ are presented results from the behavioural model which includes exogenous instrument for personality. Roter score has negative sign so that the belief that outcomes are the results of fate or luck has negative influence on earnings. Other variables have same signs as in model of Column A with a slight decrease in the size and they are statistically significant except Parental SES which is insignificant. This model is applied on 915 observations. In columns C and D coefficients on personality variables are significant and suggest that $1 \%$ deviation change in aggression is associated with almost $8 \%$ decrease in wages, and $1 \%$ decrease in withdrawal is associated with over 3\% decrease in wages. The increase in variance from including personality is larger than the mean increase in explained variance from including cognitive scores to wage determination. This model has 1123 observations. Results in table $3{ }^{5}$ show that, in high status column one standard deviation increase in aggression of women decrease women's earnings by more than $7 \%$, while the same change is associated with an average increase in men's earnings by almost 15\%. One standard deviation increase in withdrawal is associated with a decrease in men's wages by $17 \%$ and $15 \%$ for high and low status occupations, respectively. For, women changes in withdrawal are associated with a $6 \%$ increase in wages for high status women and $6 \%$ decrease in wages for women in low status occupations. The model provides following solution to the puzzles identified in question 3 . First the unexplained variance in the standard earnings function is due in part to individual differences in behavioural traits that are rewarded on labour markets. Second, the contribution of schooling and parental socioeconomic status to earnings is in part explained by earnings-enhancing behaviours learned or genetically transmitted from parents, or by additional years of schooling. Third, the apparent labour market returns to such traits as good housekeeping and slim figures reflect the co variation of these traits with behaviours sought by employers. Finally contradictory 
evidence on the effectiveness of school resources may not be puzzle at all. If incentive -enhancing preferences and other behavioural traits are important determinants of earnings, and some of these are fostered by higher quality schooling, enhanced school resources may have important effects on subsequent earnings without having large significant effects on cognitive achievement.

\section{Summary}

Personnel economics has been widely defined as an application of mathematical approaches, econometric statistical methods to the questions of human resource management, Lazear (2008). This essay reviewed some of the theoretical and empirical literature on the subject of training earnings and grooming as well as mincerian related variables to wages. Finally, the main founds are : as, post productivity returns to training are higher than wage returns, firms find profitable to pay for the general training, the returns to age, which proxy labour experience are positive statistically significant in the early years, but negative in later years negative sign on $\mathrm{AGE}^{2} / 100$. Whites earn more than their minority counterparts, education contributes positively to earnings. Marriage has positive effect on men's wages but has no significant effect on those of women. Extra time spent on grooming has positive significant effect for men that earn $5 \%$ higher wages; this coefficient is positive but insignificant for women's earnings. If disequilibrium rents arising from technological shocks are persistent and if labour services are not subject to costless enforceable contracts, individual behavioural traits unrelated to productive capacities may bear a positive price. If incentive -enhancing preferences and other behavioural traits are important determinants of earnings, and some of these are fostered by higher quality schooling, enhanced school resources may have important effects on subsequent earnings without having large significant effects on cognitive achievement. 


\section{Appendix 1}

Table 1.1 Some predictions of human capital theory

\begin{tabular}{|c|c|c|c|c|}
\hline $\begin{array}{l}\text { Row } \\
\text { No. }\end{array}$ & Model & who pays & $\begin{array}{l}\text { Divergence between wages } \\
\text { (w) and Net marginal Productivity at } \\
\text { Training firm }\end{array}$ & $\begin{array}{l}\text { Transferability of } \\
\text { Training }\end{array}$ \\
\hline [1] & $\begin{array}{l}\text { Perfect competition, } \\
\text { general training }\end{array}$ & Worker & None & Fully tran sferable \\
\hline [2] & $\begin{array}{l}\text { As above but with credit } \\
\text { Constraints }\end{array}$ & it Sharing & $\begin{array}{l}\mathrm{w}>\mathrm{MP} \text { during training and } \\
\mathrm{w}<\mathrm{MP} \text { after training }\end{array}$ & $\begin{array}{l}\text { Transferable but wage } \\
\text { returns elsewhere }\end{array}$ \\
\hline
\end{tabular}

Greater than returns at

firm providing training

\begin{tabular}{|c|c|c|c|c|}
\hline \multirow[t]{2}{*}{ [3] } & Perfect competition & Sharing & $\mathrm{w}>\mathrm{MP}$ during training & Non-transferable \\
\hline & Specific training & & $\mathrm{W}<\mathrm{MP}$ after training & \\
\hline \multirow[t]{3}{*}{ [4] } & Perfect competition, & Sharing & $\mathrm{w}>\mathrm{MP}$ during training & Partially transferable; \\
\hline & Mix of general and & & $\mathrm{W}<\mathrm{MP}$ after training & wage returns elsewhere \\
\hline & Specific training & & & less than returns at firm \\
\hline \multirow[t]{3}{*}[5]{} & Oligopolistic labour & Firm & $\mathrm{W}<\mathrm{MP}$ during and after training & Fully transferable \\
\hline & Market, general & & implying rents for the firm & wage returns elsewhere \\
\hline & Training & & & eater than returns at firm \\
\hline
\end{tabular}




\section{Appendix 2}

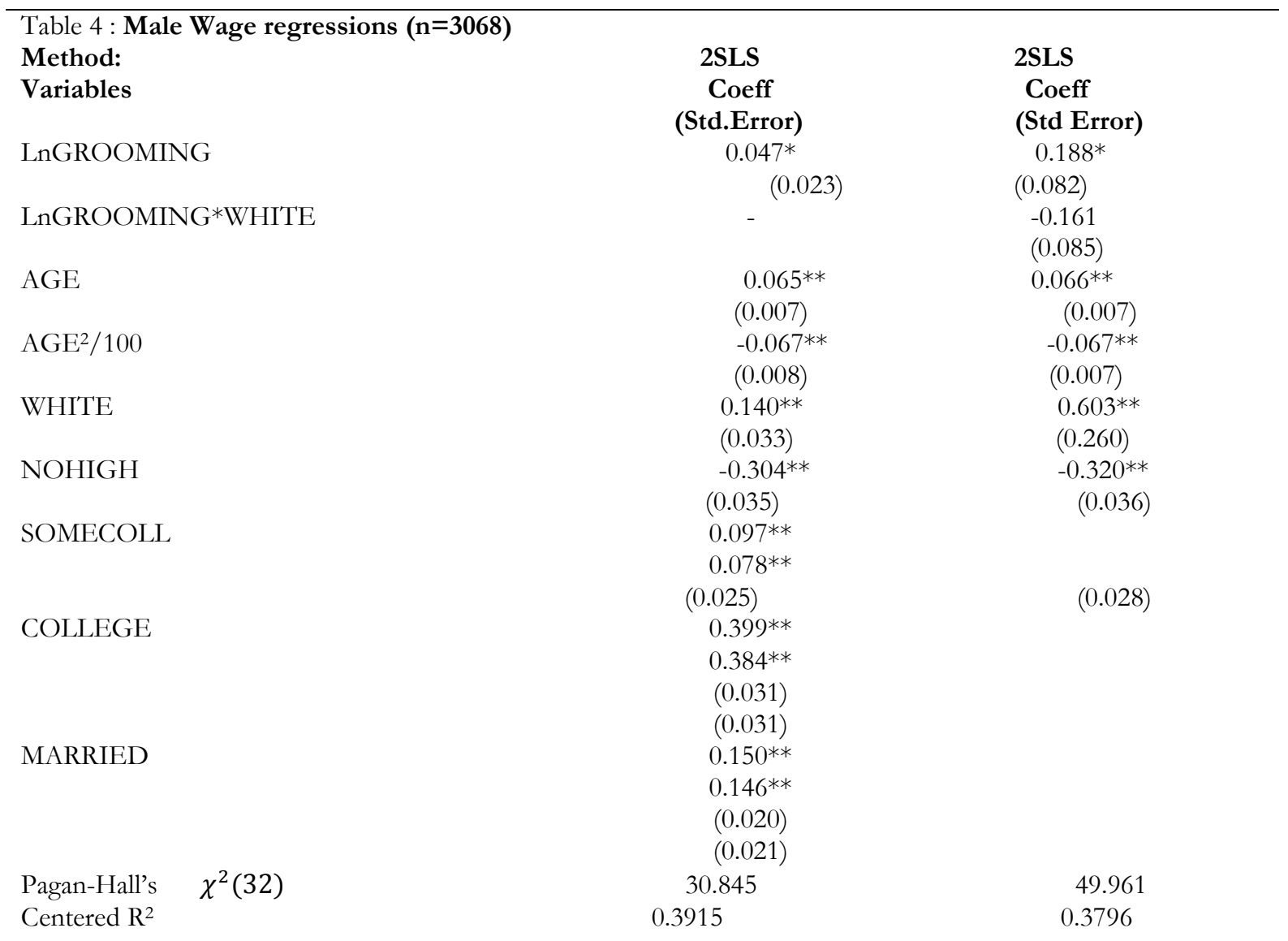

These * and $* *$ represent statistical significance at the 0.05 and 0.01 levels. 


\begin{tabular}{|c|c|c|}
\hline \multicolumn{3}{|c|}{ Table 5: Female Wage regressions $(n=2837)$} \\
\hline Method: & GMM & GMM \\
\hline Variables & $\begin{array}{l}\text { Coeff } \\
\text { (Std.Error) }\end{array}$ & $\begin{array}{c}\text { Coeff } \\
\text { (Std Error) }\end{array}$ \\
\hline LnGROOMING & $\begin{array}{l}0.023 \\
(0.027)\end{array}$ & $\begin{array}{c}0.066 \\
(0.070)\end{array}$ \\
\hline LnGROOMING*WHITE & - & $\begin{array}{c}-0.054 \\
(0.075)\end{array}$ \\
\hline AGE & $\begin{array}{r}0.059^{* *} \\
(0.006)\end{array}$ & $\begin{array}{r}0.058^{* *} \\
(0.006)\end{array}$ \\
\hline $\mathrm{AGE}^{2} / 100$ & $\begin{array}{l}-0.059^{* * *} \\
(0.007)\end{array}$ & $\begin{array}{c}-0.059^{* *} \\
(0.007)\end{array}$ \\
\hline WHITE & $\begin{array}{c}0.051^{* *} \\
(0.024)\end{array}$ & $\begin{array}{c}0.236^{* *} \\
(0.256)\end{array}$ \\
\hline NOHIGH & $(0.045)^{-0.281 * *}$ & $\begin{array}{l}-0.126^{* *} \\
(0.046)\end{array}$ \\
\hline SOMECOLL & $\begin{array}{l}0.128^{* *} \\
(0.027)\end{array}$ & $\begin{array}{l}0.126^{* *} \\
(0.027)\end{array}$ \\
\hline COLLEGE & $\begin{array}{l}0.477^{* *} \\
(0.031)\end{array}$ & $\begin{array}{l}0.476^{* *} \\
(0.030)\end{array}$ \\
\hline MARRIED & $\begin{array}{c}-0.017 \\
(0.019)\end{array}$ & $\begin{array}{r}-0.008 \\
(0.019)\end{array}$ \\
\hline Pagan-Hall's $\quad \chi^{2}(32)$ & $50.637^{* *}$ & $53.434 * *$ \\
\hline Centered R2 & 0.3689 & 0.3649 \\
\hline
\end{tabular}




\section{Appendix 3}

Table 2 Conventional and Behavioural Wage Equations

\begin{tabular}{|c|c|c|c|c|}
\hline & \multicolumn{2}{|c|}{ NLYSW } & \multicolumn{2}{|c|}{ NCDS } \\
\hline & $\begin{array}{l}\text { extended human capital } \\
\text { model A }\end{array}$ & behavioural model B & $\begin{array}{l}\text { extended human capital } \\
\text { model C }\end{array}$ & behavioural model D \\
\hline Variable: & $\mathrm{b}$ (stat) $\mathrm{b}^{\prime}$ & $\mathrm{b}$ (stat) $\mathrm{b}^{\prime}$ & $\mathrm{b}$ (stat) $\mathrm{b}^{\prime}$ & $\mathrm{b}$ (stat) $\mathrm{b}^{\prime}$ \\
\hline \multirow{2}{*}{ Years of education } & $0.079(10.467)$ & $0.071(6.299)$ & $0.108(9.638)$ & $0.104(9.264)$ \\
\hline & 0.196 & 0.179 & 0.204 & 0.197 \\
\hline \multirow{2}{*}{ IQ Score } & $0.066(4.937)$ & $0.063(4.789)$ & $0.006(2.996)$ & $0.014(2.626)$ \\
\hline & 0.081 & 0.077 & 0.058 & 0.056 \\
\hline "O" Exams & & & $0.018(3.258)$ & $0.0019(0.861)$ \\
\hline completed* & & & 0.071 & 0.018 \\
\hline \multirow{3}{*}{$\begin{array}{l}\text { Years of work } \\
\text { experience }\end{array}$} & 0.0092 & 0.0083 & & \\
\hline & $(2.399)$ & $(2.172)$ & & \\
\hline & 0.035 & 0.032 & & \\
\hline \multirow{3}{*}{ Parental SES } & 0.0095 & 0.0087 & & \\
\hline & $(1.476)$ & $(1.365)$ & $* *$ & $* *$ \\
\hline & 0.025 & 0.023 & & \\
\hline \multirow{3}{*}{ Number of children } & -0.073 & -0.072 & & \\
\hline & $(-6.278)$ & $(-6.299)$ & & \\
\hline & -0.096 & -0.094 & & \\
\hline \multirow{3}{*}{ Rotter score } & & -0.028 & & \\
\hline & & $(-4.481)$ & & \\
\hline & & -0.067 & & \\
\hline \multirow{3}{*}{ Aggression } & & & & -0.098 \\
\hline & & & & $(-3.912)$ \\
\hline & & & & -0.076 \\
\hline \multirow{3}{*}{ Withdrawal } & & & & -0.040 \\
\hline & & & & $(-2.127)$ \\
\hline & & & & -0.033 \\
\hline Adjusted $\mathrm{R}^{2}$ & 0.327 & 0.341 & 0.245 & 0.259 \\
\hline Observations & 915 & 915 & 1123 & 1123 \\
\hline
\end{tabular}

Notes: All regressions include a constant and are white females actively employed in the year that wages are Measured (from Osborne 2000)

*"0" level exams indicate the number of completed Ordinary Level Exams to age 21.

** Socioeconomic status is also included in the model; however, it is not reported here because it is not statistically significant, in either model. 
By Sex and Predicted Occupational Status

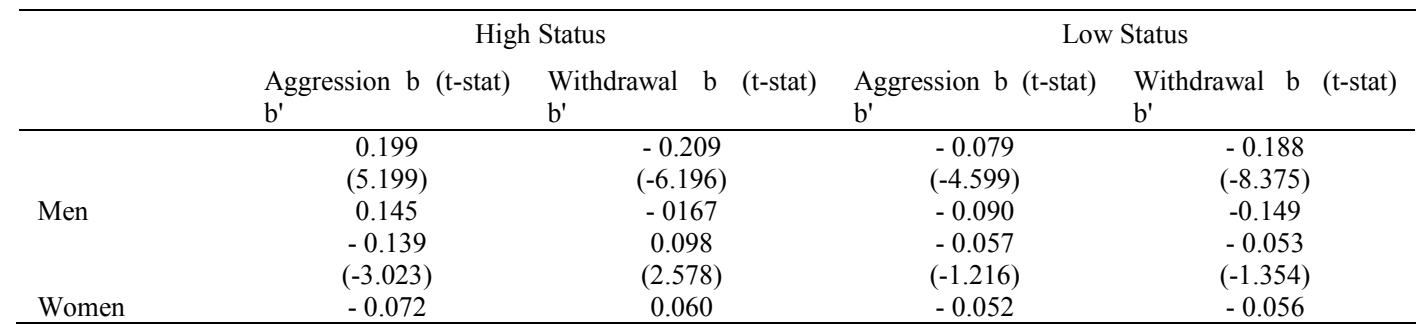

Notes: All regressions include a constant and are for white women actively employed in 1991 when wages are measured. The dependent variable is the natural log of self-disclosed hourly wages in in 1991, when respondents were 33 years of age. The coefficients b' represents the percentage change in wages from a one standard deviation change in the independent variable $\left(b^{\prime} x=b_{x} \sigma_{x}\right)$

\section{References}

1. Bassanini, A., Booth,A., Brunello,G.,Paola De,M., Leuven E.,(2005), Workplace Training in Europe, IZA DP No. 1640, Discussion papers

2. Becker,S.G., (1993), Human Capital: A Theoretical and Empirical Analysis, with Special Reference to Education. Chicago, University of Chicago Press

3. Bowles, S.,Herbert,G., Melissa,O.,(2001), The determinants of earnings: A behavioral approach, University of Massachusets Amherst college

4. Das,J., DeLoach, S.,B.,2008. "Mirror, mirror on the wall: The effect of time spent grooming on wages," Working Papers 2008-01, Elon University, Department of Economics.

5. Edward,L., 2008. "Personnel economics," The New Palgrave Dictionary of Economics, 2nd Edition, v. 6, p. 380 [pp. 380-84] 